Солодка Ольга,

доктор економічних наук, доцент,

Київський національний університет імені Тараса Шевченка,

кафедра фінансів,

м. Київ, ORCID ID 0000-0002-0974-3068,

e-mail: oosolodkaya@gmail.com

https://doi.org/10.29038/2411-4014-2020-03-15-22

\title{
ФОРМУВАННЯ СИНТЕТИЧНОЇ ФОРВАРДНОЇ ПОЗИЦЇ̈ ДЛЯ ВИЗНАЧЕННЯ РІВНЯ КООРДИНАЦІЙНИХ ДЕСТРУКЦІЙ В ЕКОНОМІЦІ
}

В статті актуалізовано необхідність розробки методології ефективного запровадження похідних фінансових інструментів у фінансово-економічну діяльність суб'єктів господарювання. Обгрунтовано доцільність створення методології предикативної аналітики для визначення рівня координаційних деструкцій в економіці у розрізі грошово-кредитного, валютного, фондового і товарно-сировинного ринків для об'єктноорієнтованого структурного моделювання 3 метою мінімізації ринкових деструкцій. Рівень координаційних деструкцій на ринку визначено як тривале односпрямоване відхилення рівноважних значень параметрів предикатів ринків від їх фактичних значень, що засвідчує недієвість ринкових механізмів попиту і пропозиції на даному ринку. Розроблено механізм формування синтетичної форвардної позиції для визначення рівноважних значень параметрів предикатів ринків із подальшим визначенням рівня координаційних деструкцій в економіці.

Ключові слова: синтетична форвардна позиція, координаційні деструкції, похідний фінансовий інструмент, макроекономічна рівновага, фінансовий інструмент, справедлива форвардна ціна, предикат ринку.

Солодкая Ольга, доктор экономических наук, доцент, Киевский национальный университет имени Тараса Шевченко, кафедра финансов, г. Киев

\section{ФОРМИРОВАНИЕ СИНТЕТИЧЕСКОЙ ФОРВАРДНОЙ ПОЗИЦИИ ДЛЯ ОПРЕДЕЛЕНИЯ УРОВНЯ КООРДИНАЦИОННЫХ ДЕСТРУКЦИИ В ЭКОНОМИКЕ}

В статье актуализирована необходимость разработки методологии эффективного внедрения производных финансовых инструментов в финансово-экономическую деятельность субъектов хозяйствования. Обоснована целесообразность создания методологии предикативной аналитики для определения уровня координационных деструкций в экономике в разрезе денежно-кредитного, валютного, фондового и товарно-сырьевого рынков для объектно-ориентированного структурного моделирования с целью минимизации рыночных деструкций. Уровень координационных деструкций на рынке определен как длительное однонаправленное отклонение равновесных значений параметров предикатов рынков от их фактических значений, что подтверждает неэффективность рыночных механизмов спроса и предложения на данном рынке. Разработан механизм формирования синтетической форвардной позиции для определения равновесных значений параметров предикатов рынков с дальнейшим определением уровня координационных деструкций в экономике.

Ключевые слова: синтетическая форвардная позиция, координационные деструкции, производный финансовый инструмент, макроэкономическое равновесие, финансовый инструмент, справедливая форвардная цена, предикат рынка.

Olha Solodka,

Doctor of Economic Sciences, Associate Professor, Taras Shevchenko National University of Kyiv, Finance department,

Kyiv 


\section{CREATION OF A SYNTHETIC FORWARD POSITION TO DETERMINE THE LEVEL OF COORDINATION DESTRUCTIONS IN THE ECONOMY}

The article actualizes the need to develop a methodology for the effective implementation of derivatives in the activities of economic entities. The expediency of creating a methodology of predictive analytics for determining the level of coordination destructions in the economy in the context of the monetary, foreign exchange, stock, and commodity markets is substantiated. This methodology is designed for object-oriented structural modeling to minimize market destructions. It is proposed to define coordination destructions in the economy as a violation of macroeconomic equilibrium in the direction of its non-optimal states. The reason for this is the impossibility of mutually beneficial coordination of economic entities. The consequence of this is the negative dynamics of macroeconomic indicators. The level of coordination destructions in the market is defined as a long unidirectional deviation of the equilibrium values of the parameters of market predicates from their actual values. The presence of coordination destructions proves the inefficiency of market mechanisms of supply and demand in this market.

The formation of a synthetic forward position is based on the algorithm for determining the fair forward price of a financial instrument. It is proved that a synthetic forward position is formed through spot parameter rates of one set of financial instruments to determine fair forward parameter rates of another set of financial instruments. This provides systemic links between the structural elements of the economic system and the effective redistribution of financial resources. It is substantiated that a synthetic forward position allows one to determine equilibrium forward exchange rates for the predicates of the monetary, foreign exchange, stock, and commodity markets. A mechanism has been developed for the formation of a synthetic forward position to determine the equilibrium values of the parameters of market predicates. This mechanism is needed to determine the level of coordination destructions in the economy.

Keywords: synthetic forward position, coordination destructions, derivative, macroeconomic equilibrium, financial instrument, fair forward price, market predicate.

Постановка проблеми. Економіка України характеризується високим ступенем макроекономічної і фінансової нестабільності, джерелами якої є перманентна наявність системних і координаційних деструкцій грошово-кредитного, валютного, фондового і товарно-сировинного ринків. За таких умов актуальним є активне використання деривативів для хеджування економічних і фінансових ризиків окремих суб’єктів господарювання. Незважаючи на те, що розвиток ринку деривативів України розпочато ще у 1994 році, наразі його частка складає менше 1\% загального обсягу торгів на фондовому ринку. На наш погляд, причиною даної суперечності є відсутність грунтовної методології ефективного запровадження похідних фінансових інструментів у фінансовоекономічну діяльність суб'єктів господарювання, фрагментарне неадаптоване запровадження фінансовими посередниками відповідного зарубіжного досвіду без системного аналізу економічних умов і передумов використання різних видів деривативів, відірваність фінансового системи від розвитку реального сектору економіки України. У зв’язку з цим, актуальною є розробка методології предикативної аналітики для визначення рівня координаційних деструкцій в економіці у розрізі грошово-кредитного, валютного, фондового i товарно-сировинного ринків для об'єктноорієнтованого структурного моделювання з метою мінімізації ринкових деструкцій. Елементом даної методології є механізм формування синтетичної форвардної позиції для визначення рівноважних значень параметрів предикатів ринків із подальшим визначенням рівня координаційних деструкцій.

Аналіз останніх досліджень і публікацій. Проблеми моделювання параметрів деривативів знайшли відображення в низці праць провідних зарубіжних вчених, зокрема: Ансона М. [1], Білєскі Т. [3], Бьюмонта П. [2], Грехема Б. [9], Дабіла Р. [6], Дефаско Р. [5], Додда Д. [9], Дуффі Д. [7], Еша Л. [8], Кефера Р. [8], Лопез Т. [8], Мана Дж. [11], Рутковскі М. [3], Фабоцци Ф. [1], Халла Дж. [10], Чадрі М. [1], Чена Р. [1], Чонга Ю. [4] та інших. Результати досліджень зазначених науковців стосуються внутрішнього кола взаємозв'язків ринку похідних фінансових інструментів, їх видів, комбінацій та параметрів.

Виділення невирішених раніше частин загальної проблеми. Макроекономічний аспект механізмів використання похідних фінансових інструментів не знайшов системного відображення в сучасній економічній науці. Разом із тим, саме макроекономічний аспект є основою обгрунтування адекватності запровадження окремих видів похідних фінансових інструментів у конкретну економічну систему 3 метою мінімізації координаційних деструкцій у розрізі ринків для забезпечення макроекономічної і фінансової стабільності. 
Метою статті $є$ розробка механізму формування синтетичної форвардної позиції для визначення рівноважних значень параметрів предикатів ринків із подальшим визначенням рівня координаційних деструкцій в економіці.

Виклад основного матеріалу. Координаційні деструкції в економіці ми пропонуємо визначати, як порушення макроекономічної рівноваги у напрямі виникнення іiі неоптимальних станів внаслідок неможливості взаємовигідної координації дій суб’єктів господарювання, що має наслідком негативну динаміку макроекономічних показників [12; 13].

Зауважимо, що динамічний стан економіки передбачає множину рівноважних макроекономічних станів, які, в залежності від ділових очікувань суб'єктів господарювання, можуть бути бажаними або небажаними, тобто не будь-який стан макроекономічної рівноваги $\epsilon$ оптимальним. Координаційні деструкції в економіці призводять до виникнення неоптимальних станів макроекономічної рівноваги. При цьому, макроекономічна нестабільність $є$ цілком природньою, оскільки виникає внаслідок руху економіки від одного рівноважного стану до іншого при відповідних ділових очікуваннях суб'єктів господарювання. Оскільки економічна система характеризується циклічністю розвитку, стан абсолютної макроекономічної стабільності є умовним в силу перманентної наявності координаційних деструкцій в економіці. У зв'язку 3 цим, макроекономічну стабільність запропоновано розглядати як динаміку оптимальних станів макроекономічної рівноваги [13]. Враховуючи значене, вважаємо за доцільне визначення рівня координаційних деструкцій у розрізі фондового, грошово-кредитного, валютного і товарносировинного ринків за допомогою предикативної моделі.

Згідно нашої наукової позиції, мінімізація рівня координаційних деструкцій в економіці України забезпечується через наближення станів зазначених ринків до рівноважних. У зв'язку з цим, необхідним $\epsilon$ визначення способу знаходження рівноважних значень параметрів предикатів фондового, грошово-кредитного, валютного i товарно-сировинного ринків. Тоді відхилення рівноважних значень параметрів предикатів ринків від їх фактичних значень засвідчить відповідний рівень координаційних деструкцій. Таким чином, рівень координаційних деструкцій на ринку визначається тривалим односпрямованим відхиленням рівноважних значень параметрів предикатів ринків від їх фактичних значень, що засвідчує недієвість ринкових механізмів попиту і пропозиції на даному ринку. На наш погляд, знайти рівноважні значення параметрів предикатів фондового, грошово-кредитного, валютного і товарно-сировинного ринків можна через побудову синтетичної форвардної позиції. Формування синтетичної форвардної позиції грунтується на алгоритмі визначення справедливої форвардної ціни фінансового інструменту.

Нехай маємо довгу форвардну позицію на фінансовий інструмент, за яким не сплачуються дивіденди. Така позиція передбачає, що інвестор (покупець) зобов'язаний на момент експірації позиції, тобто в кінці терміну іiї дії Т, сплатити продавцеві фінансового інструменту суму коштів, яка дорівнює форвардній ціні фінансового інструменту, в обмін на цей фінансовий інструмент $[1 ; 3 ; 7$; 10; 11]. Разом із тим, інвестор має можливість отримати результат, аналогічний довгій форвардній позиції на фінансовий інструмент, в інший спосіб. Для цього, в поточний момент часу, треба запозичити суму коштів, що дорівнює спот-курсу фінансового інструменту $\mathrm{S}$ на період $\mathrm{T}$ під відсоток $\mathrm{r}$, купити фінансовий інструмент, тримати його протягом визначеного періоду. В кінці періоду T інвестор сплатить за кредитом (як і за форвардною позицією) суму F. Таким чином, результатом зазначених дій інвестора в кінці терміну Т $є$ володіння фінансовим інструментом внаслідок сплати його форвардної ціни. Інакше кажучи, довга форвардна позиція інвестора аналогійна описаному алгоритму його дій з точки зору витрат і результату.

Коротка форвардна позиція на фінансовий інструмент, за яким не сплачуються дивіденди, передбачає, що ії власник зобов'язаний на момент експірації позиції, тобто в кінці терміну ії дії Т, продати фінансовий інструмент за форвардною ціною $\mathrm{F}[2 ; 4 ; 5 ; 6 ; 8 ; 9]$. Метою в даному випадку $є$ отримання коштів у сумі $\mathrm{F}$, тому коротка форвардна позиція аналогійна такому алгоритму дій продавця, з точки зору витрат і результату: продаж у поточний момент часу фінансового інструменту за його спот-ціною $\mathrm{S}$, розміщення суми $\mathrm{S}$ на депозит терміном Т під відсоток $\mathrm{r}$.

Форвардна ціна фінансового інструменту визначається за формулою:

F - форвардна ціна фінансового інструменту;

$$
\mathrm{F}=\mathrm{S}\left(1+\mathrm{r} \frac{\mathrm{T}}{\text { база }}\right) \text {, де }
$$


$\mathrm{S}$ - спот-ціна фінансового інструменту;

$\mathrm{r}$ - ставка без ризику;

Т - період дії форвардної позиції;

база - фінансовий рік.

Таким чином, загальний алгоритм визначення форвардної ціни фінансового інструменту визначиться в такий спосіб: форвардна ціна фінансового інструменту дорівнює його спот-ціні плюс відсоток без ризику на спот-ціну за період дії форвардної позиції.

В обох розглянутих випадках наявною є байдужість власника синтетичної форвардної позиції між іiі обранням і аналогічними діями. Таким чином, синтетична форвардна позиція визначає справедливу (рівноважну) ціну фінансового інструменту. Наведений алгоритм визначення справедливої (рівноважної) форвардної ціни ми пропонуємо використовувати при визначенні синтетичної форвардної позиції для інструментів фондового, грошово-кредитного і товарносировинного ринків.

Синтетичну форвардну позицію ми пропонуємо визначати як форму арбітражу, яка являє собою сукупність грошових потоків, створених через композицію або декомпозицію сукупності грошових потоків для однієї множини фінансових інструментів, які відтворюють (реплікують) сукупності грошових потоків для іншої множини фінансових інструментів. Інакше кажучи, синтезовані сукупності грошових потоків відтворюють сукупності грошових потоків реальних інструментів, а отже є синтетичними інструментами.

Синтетична форвардна позиція формується через спот-курси параметрів однієї множини фінансових інструментів для визначення справедливих (рівноважних) форвардних курсів параметрів іншої множини фінансових інструментів, що, на нашу думку, забезпечує системні зв'язки між структурними елементами економічної системи у розрізі ефективного перерозподілу фінансових ресурсів, а отже сприяе ії наближенню до стану динамічної макроекономічної рівноваги. Таким чином, синтетична форвардна позиція дозволяє визначити рівноважні форвардні курси параметрів предикатів фондового, грошово-кредитного і товарно-сировинного ринків.

Визначення синтетичної форвардної позиції для інструментів валютного ринку, на наш погляд, потребує уточнень. Нехай необхідно визначити справедливий форвардний валютний курс UAH/EUR через відрізок часу T, тобто параметр предметної множини інструментів валютного ринку. Для визначення справедливого форвардного валютного курсу слід зробити припущення, що процентна ставка за кредитами дорівнює процентній ставці за депозитами протягом періоду Т. Вхідною інформацією для формування синтетичної форвардної позиції є спот-курс UAH/EUR i параметри множини інструментів грошово-кредитного ринку, зокрема: процентна ставка за UAH, процентна ставка за EUR.

\section{Синтетична форвардна позиція}

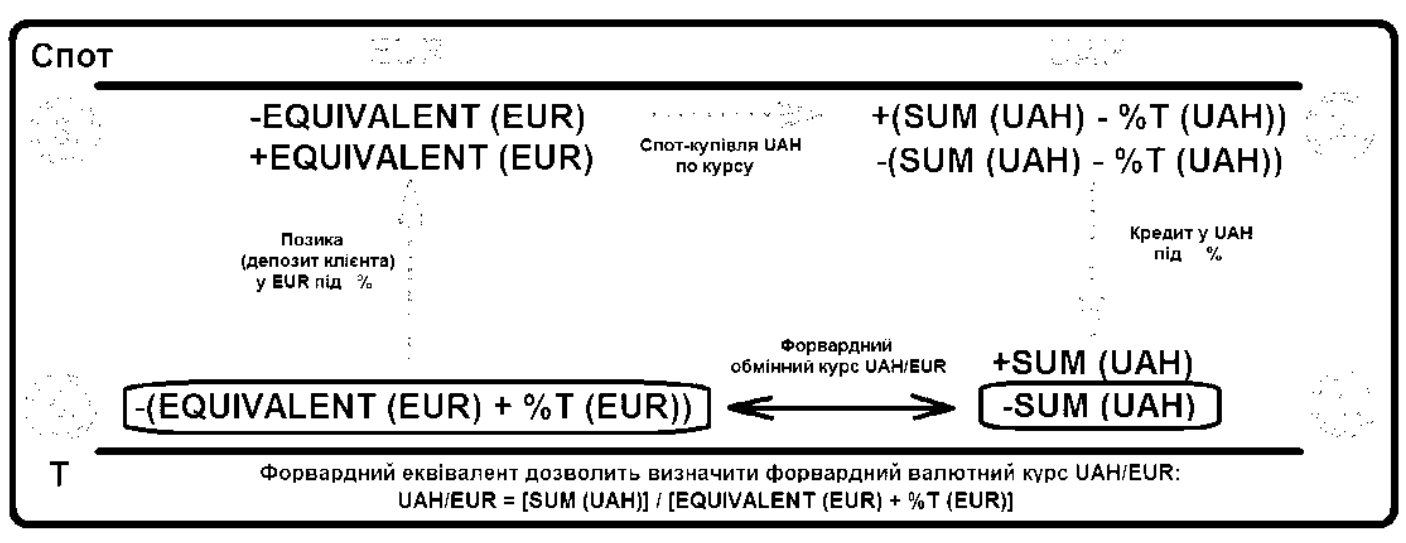

Рис. 1. Синтетична форвардна позиція для інструментів валютного ринку

Джерело: власна розробка автора 
Композиція грошових потоків, що формують синтетичну форвардну позицію для інструментів валютного ринку, наведено на рис. 1. Композицію побудовано, виходячи з необхідності обміну деякої суми SUM у UAH (грошовий потік 1) через відрізок часу T, через визначення послідовності дій (угод), яка дозволила хеджеру (наприклад, банку) хеджувати форвардний обмін UAH/EUR за допомогою інших угод із відомими параметрами (відомими параметрами є спот-курс і відсоткові ставки за UAH i EUR). Зазначена послідовність дій хеджера визначилася в такий спосіб: щоб отримати на кінець періоду T суму SUM у UAH для обміну на EUR, хеджер має надати сьогодні кредит в обсязі теперішньої вартості цієї суми - грошовий потік 2 (SUM у UAH мінус відсоток за кредиток на період T); грошовий потік 2 формується через спот-купівлю даної суми за EUR грошовий потік 3 (EQUIVALENT у EUR); джерелом грошового потоку $3 є$ позика у EUR на період T - грошовий потік 4.

Таким чином, формування синтетичної форвардної позиції, тобто композиція грошових потоків 1-4, дозволила визначити форвардний еквівалент сум у UAH i EUR, співвідношення який і визначає форвардний валютний курс UAH/EUR через відрізок часу T. Інакше кажучи, реплікацією визначеної композиції грошових потоків $є$ справедливий форвардний валютний курс UAH/EUR. Отже, синтезовані сукупності грошових потоків дозволити визначити параметр справедливої вартості реального фінансового інструменту.

Формалізований варіант визначення синтетичної форвардної позиції для інструментів валютного ринку через спот-курс і процентні ставки за кредитами і депозитами має вигляд:

$$
\mathrm{F}=\mathrm{S} \times\left[\frac{1+\mathrm{r}_{\mathrm{q}} \times \frac{\mathrm{T}}{\mathrm{Basis}_{\mathrm{q}}}}{1+\mathrm{r}_{\mathrm{b}} \times \frac{\mathrm{T}}{\mathrm{Basis}_{\mathrm{h}}}}\right] \text {, де }
$$

F - справедливий форвардний валютний курс;

$\mathrm{S}$ - валютний спот-курс;

$\mathrm{r}_{\mathrm{q}}$ - процентна ставка за валютою, що котирується;

$\mathrm{r}_{\mathrm{b}}$ - процентна ставка за основною валютою;

T - форвардний період;

Basis $_{\mathrm{q}}$ - фінансовий рік для валюти, що котирується;

Basis $_{\mathrm{b}}$ - фінансовий рік для основної валюти.

Враховуючи композицію грошових потоків у даному варіанті синтетичної форвардної позиції, для реального стану валютного і грошово-кредитного ринків, з метою посилення об'єктивності розрахунків, в якості $\mathrm{r}_{\mathrm{q}}$ пропонуємо використовувати процентну ставка за кредитами для валюти, що котирується, в якості $\mathrm{r}_{\mathrm{b}}$ - процентну ставку за депозитами для основної валюти.

Рівноважні форвардні курси параметрів предикату валютного ринку пропонуємо розраховувати на предметній множини таких первісних параметрів: спот-курси валют; процентні ставки за кредитами для валюти, що котирується; процентні ставки за депозитами для основної валюти.

Крім того, на наш погляд, визначення синтетичної форвардної позиції для інструментів валютного ринку можна також здійснювати на основі теореми про паритет купівельної спроможності, згідно якої справедливі курси валют мають змінюватися у відповідності до зміни цін в межах відповідних країн. Відсутність даної пропорції відкриває можливість здійснення арбітражних операцій. Зміна цін відображається показником рівня інфляції.

Формалізований варіант визначення синтетичної форвардної позиції для інструментів валютного ринку через рівень інфляції має вигляд:

F - справедливий форвардний валютний курс;

$$
\mathrm{F}=\mathrm{S} \times\left[\frac{1+\mathrm{i}_{\mathrm{cl}}}{1+\mathrm{i}_{\mathrm{cg}}}\right] \text {, де }
$$

$\mathrm{S}$ - валютний спот-курс;

$\mathrm{i}_{\mathrm{c} 1}$ - рівень інфляції в країні, валюта якої котирується;

$\mathrm{i}_{\mathrm{c} 2}$ - рівень інфляції в країні, валюта якої є основною.

В даному випадку, рівноважні форвардні курси параметрів предикату валютного ринку пропонуємо розраховувати на предметній множини таких первісних параметрів: спот-курси валют; рівні інфляції в країні, валюта якої котирується, та в країнах, валюти яких є основними.

Таким чином, ємність предикатів m розширилася предметними множини похідних параметрів в такий спосіб: $\mathrm{m}\left(\mathrm{PR} 1_{\text {Stock market }}\right)=3 ; \mathrm{m}\left(\mathrm{PR} 2_{\text {Monetary market }}\right)=9 ; \mathrm{m}\left(\mathrm{PR} 3_{\text {Currency market }}\right)=6 ; \mathrm{m}\left(\mathrm{PR} 4_{\text {Commodity market }}\right)=$ 
3. Отже, ми пропонуємо визначати справедливу (рівноважну) форвардну ціну інструментів валютного ринку через формування синтетичної форвардної позиції на основі двох сигнатур предикату валютного ринку:

1) перша сигнатура містить предметні множини таких первісних параметрів предикату: споткурси валют; процентні ставки за кредитами для валюти, що котирується; процентні ставки за депозитами для основної валюти;

2) друга сигнатура містить предметні множини таких первісних параметрів предикату: споткурси валют; рівні інфляції в країні, валюта якої котирується, та в країнах, валюти яких є основними.

Таким чином, наша наукова позиція полягає у визначенні рівня координаційних деструкцій на фондовому, грошово-кредитному, валютному і товарно-сировинному ринках через використання синтетичної форвардної позиції.

Предикативна модель синтетичної форвардної позиції будується для зазначених ринків шляхом формування предикатів і функціональної залежності, яка $є$ формалізованим поданням модифікації синтетичної форвардної позиції для даного ринку. При цьому, предикатом є сукупність первісних і похідних параметрів ринку, структурована у вигляді предметних множин, що формують сигнатуру предикату даного ринку.

Формалізоване подання модифікації синтетичної форвардної позиції для даного ринку дозволяє визначити рівноважне значення параметрів предикату. Тоді відхилення рівноважних значень параметрів предикату ринку від їх фактичних значень визначить рівень координаційних деструкцій на даному ринку.

Відхилення рівноважних значень параметрів предикату ринку від їх фактичних значень пропонуємо визначати як форвардну маржу (своп-пукти). Форвардна маржа $\mathrm{W} \epsilon$ різницею між справедливим форвардним курсом $\mathrm{F}$ фінансового інструменту та його спот-курсом $\mathrm{S}$, тобто $\mathrm{W}=\mathrm{F}-$ S.

Для справедливого форвардного курсу інструментів валютного ринку, визначеного через споткурс і процентні ставки за кредитами i депозитами форвардна маржа $\mathrm{W}$ може бути розрахована за формулою:

$$
W=S \times\left\lceil\frac{1+r_{\mathrm{q}} \times \frac{T}{\text { Basisg }_{g}}}{1+r_{\mathrm{b}} \times \frac{T}{\text { Basis }_{\mathrm{h}}}}-1\right\rceil .
$$

Таким чином, форвардна маржа $\mathrm{W}$ визначає рівень координаційних деструкцій на даному ринку.

В розрізі предмету дослідження, важливою характеристикою форвардної маржі $\epsilon$ рівень іï чутливості до зміни спот-курсів відповідних фінансових інструментів. Проілюструємо зазначене на прикладі. Нехай спот-курс UAH/USD = 27/1. Процентна ставка за кредитами дорівнює процентній ставці за депозитами. Процентна ставка за UAH складає 13\%. Процентна ставка за USD складає 7\%. Припустимо, що спот-курс UAH/USD збільшився на 343 пункти $(0,0343)$. Рівень чутливості справедливого річного форвардного валютного курсу і форвардної маржі до такої зміни наведено на рис. 2.

\begin{tabular}{|c|c|c|c|c|c|}
\hline & Kypc UAH/USD & \% UAH & \% USD & Зміна & \\
\hline Спот 1 & 27,0000 & $13,00 \%$ & $7,00 \%$ & 0,0343 & \\
\hline Форвард 1 & 28,5140 & & & & \\
\hline \multirow[t]{3}{*}{ Своп-пункт 1} & 1,5140 & & & ень чутливост & сті до зміни спот-курсу: \\
\hline & & & $-0,0362$ & рвардного вал & алютного курсу 362 пункти \\
\hline & & & $-0,0019$ & рвардної марх & ржі 19 пунктів \\
\hline Спот 2 & 27,0343 & & & & \\
\hline Форвард 2 & 28,5502 & & & & \\
\hline Своп-пункт 2 & 1,5159 & & & & \\
\hline
\end{tabular}

Рис. 2. Рівень чутливості справедливого річного форвардного валютного курсу $і$ форвардної маржі до збільшення валютного спот-курсу

Джерело: власна розробка автора

Отже, рівень чутливості форвардної маржі до зміни спот-курсу майже в 20 разів менший за чутливість справедливого форвардного валютного курсу. Таким чином, форвардна маржа є суттєво 
менш чутливою до зміни спот-курсів фінансових інструментів, ніж їх справедливий форвардний курс, тому більш придатна для визначення загальних макроекономічних тенденцій, зокрема рівня координаційних деструкцій в економіці.

В процесі побудови предикативної моделі визначення рівня координаційних деструкцій у розрізі ринків слід розрахувати форвардну маржу для предикатів фондового, грошово-кредитного, валютного i товарно-сировинного ринків. Для визначення інтегрованого показника рівня координаційних деструкцій на даному ринку DL (інтегрованого результативного параметру предикативної моделі) через значення форвардної маржі, пропонуємо лінійну трендову модель, тобто лінійний тренд до графіку форвардної маржі. Тоді, рівняння лінії тренду є моделлю рівня координаційних деструкцій на даному ринку.

Рівняння лінії тренду містить кутовий коефіцієнт, який дорівнює тангенсу кута нахилу прямої до осі ОХ. Кут нахилу прямої визначається в межах від 0 до 180 градусів. Рівняння лінії тренду має вигляд у $=\mathrm{DLx}+\mathrm{b}$, де коефіцієнт DL - кутовий коефіцієнт, $\mathrm{DL}=\operatorname{tg} \alpha$. Кутовий коефіцієнт $0 \leq|\operatorname{tg} \alpha| \leq$ $\infty$ визначає рівень координаційних деструкцій на даному ринку. Критерієм оптимальності моделі $€$ мінімізація координаційних деструкцій на даному ринку, тобто DL $\rightarrow 0$, що визначається прямуванням кутового коефіцієнту до нуля, $|\operatorname{tg} \alpha| \rightarrow 0$.

Слід зазначити, що від'ємне значення кутового коефіцієнту лінійного тренду до графіку форвардної маржі означає, що фактичні значення параметрів предикатів були переважно меншими за рівноважні (тобто синтетичні форвардні позиції були більшими за фактичні значення параметрів у більшості розглянутих випадків). I навпаки, для додатного значення кутового коефіцієнту. Отже, рівень координаційних деструкцій слід визначати через абсолютне значення кутового коефіцієнту лінійного тренду до графіку форвардної маржі предикатів фондового, грошово-кредитного, валютного і товарно-сировинного ринків.

Висновки та пропозиції. Рівень координаційних деструкцій в економіці у розрізі ринків дозволяє визначити пріоритетність активізації запровадження похідних фінансових інструментів для їх мінімізації на основі створення механізмів хеджування економічних і фінансових ризиків суб'єктів господарювання. Згідно нашої наукової позиції, рівень координаційних деструкцій в економіці підлягає мінімізації через похідні фінансові інструменти, якщо відповідні базові активи пов'язані 3 діяльністю потенційних хеджерів. Тоді фінансові деривативи хеджують ризики зміни цін базових активів, отже забезпечують прибуткову діяльність хеджерів і фінансову стабільність на мікрорівні, що, у свою чергу, сприяє економічному розвитку реального сектору економіки, наслідком чого $€$ макроекономічна і фінансова стабільність. Крім того, на наш погляд, посилення синергетичного ефекту стратегій хеджування на макроекономічному рівні забезпечується такими похідними фінансовими інструментами, базові активи яких є точкою перетину діяльності двох суб'єктів господарювання - учасників строкових контрактів. У такому випадку, цінові ризики обох хеджерів $€$ дзеркально протилежними та гармонійно поєднуються у одному строковому контракті, компенсуючи один одного та не провокуючи появи спекулянту, як альтернативного учасника контракту (хеджер - спекулянт). Таким чином, визначення рівня координаційних деструкцій в економіці у розрізі ринків $є$ основою для побудови модульних профілів потенційних хеджерів із їх подальшою деталізацією на основі моделювання параметрів похідних фінансових інструментів у стратегіях хеджування.

На наш погляд, ефективність використання методології предикативної аналітики суттєво залежить від однозначності встановлених цілей, надійності інформаційних джерел, достовірності та повноти вхідної інформації, коректності структуризації та формалізованого подання інформаційних сукупностей, адекватності предикатів і моделі предикативної аналітики. У зв'язку з цим, розроблена методологія предикативної аналітики у визначенні координаційних деструкцій в економіці має охоплювати моделі, методи та інструменти фундаментального і технічного аналізу кон'юнктурних коливань, асиметричності, неефективності та нестабільності ринків базових активів похідних фінансових інструментів

Запропонований нами і розкритий у даній статті механізм формування синтетичної форвардної позиції для визначення рівноважних значень параметрів предикатів ринків із подальшим визначенням рівня координаційних деструкцій в економіці $\epsilon$ новим, на світовому рівні, методологічним підходом до визначення пріоритетності активізації запровадження деривативів у 
стратегіях хеджування економічних і фінансових ризиків суб'єктів господарювання відповідно до поточної та прогнозної кон'юнктури ринків базових активів.

\section{Джерела та література}

1. Anson M.J., Fabozzi F.J., Chudhry M., Chen R.-R. Credit Derivatives: Instruments, Applications, and Pricing. New Jersey: John Wiley \& Sons, Inc, 2004. 354p.

2. Beaumont P.H. Financial Engineering Principles. A Unifield Theory for Financial Product Analysis and Valuations. New Jersey: John Wiley \& Sons, Inc, 2009. 318p.

3. Bielecki T., Rutkowski M. Credit Risk: Modeling, Vaiuation and Heding. M. . Berlin: Spinger-Verlag Berlin Heidelberg, 2002. 500p.

4. Chong Y.Y. Investment Risk Management. Chichester: John Wiley \& Sons Ltd, 2004. 223p.

5. DeFusco R.A., McLeavey D.W., Pinto J.E., Runrle D.E. Quantitative Investment Analysis. New York: John Wiley \& Sons, Inc, 2007. 729p.

6. Dubil R. An Arbitrage Guide to Financial Markets. Chichester: John Wiley \& Sons Ltd, 2004. 346p.

7. Duffy D.J. Finite Difference Methods in Financial Engineering. A Partial Differential Equation Approach. Chichester: John Wiley \& Sons Ltd, 2006. 442p.

8. Esch L., Kieffer R., Lopez T. Asset and Risk Management. Risk Oriented Finance. Chichester: John Wiley \& Sons Ltd, 2005. 416p.

9. Graham B., Dodd D. Security Analysis: Principles and Technique. New York: McGraw-Hill, 2009. 766p.

10. Hull J.C. Risk Management and Financial Institutions. New Jersey: John Wiley \& Sons, Inc, 2015. 752p.

11. Mun J. Real Options Analysis Course. Business Cases and Software Applications. New Jersey: John Wiley \& Sons, Inc, 2003. 318p.

12. Solodka O.O. Parameters of pricing of forward and futures contracts. International Research Conference on Science, Education, Technology and Management: Conference Proceedings, August 20th 2017. Scientific public organization Professional science. Paris: Scientific public organization Professional science, 2017. 455p. P.269-286.

13. Solodka O.O. The methodology of fundamental and technical analysis in the context of the market's irrationality of derivatives. International Research Conference on Economics, Arts and Sciences: Conference Proceedings, 31 July 2017. Scientific public organization Professional science. Uppsala: Scientific public organization Professional science, 2017. 416p. P.276-301.

\section{References}

1. Anson M.J., Fabozzi F.J., Chudhry M., Chen R.-R. Credit Derivatives: Instruments, Applications, and Pricing. New Jersey: John Wiley \& Sons, Inc, 2004. 354p.

2. Beaumont P.H. Financial Engineering Principles. A Unifield Theory for Financial Product Analysis and Valuations. New Jersey: John Wiley \& Sons, Inc, 2009. 318p.

3. Bielecki T., Rutkowski M. Credit Risk: Modeling, Vaiuation and Heding. M. . Berlin: Spinger-Verlag Berlin Heidelberg, 2002. 500p.

4. Chong Y.Y. Investment Risk Management. Chichester: John Wiley \& Sons Ltd, 2004. 223p.

5. DeFusco R.A., McLeavey D.W., Pinto J.E., Runrle D.E. Quantitative Investment Analysis. New York: John Wiley \& Sons, Inc, 2007. 729p.

6. Dubil R. An Arbitrage Guide to Financial Markets. Chichester: John Wiley \& Sons Ltd, 2004. 346p.

7. Duffy D.J. Finite Difference Methods in Financial Engineering. A Partial Differential Equation Approach. Chichester: John Wiley \& Sons Ltd, 2006. 442p.

8. Esch L., Kieffer R., Lopez T. Asset and Risk Management. Risk Oriented Finance. Chichester: John Wiley \& Sons Ltd, 2005. 416p.

9. Graham B., Dodd D. Security Analysis: Principles and Technique. New York: McGraw-Hill, 2009. 766p.

10. Hull J.C. Risk Management and Financial Institutions. New Jersey: John Wiley \& Sons, Inc, 2015. 752p.

11. Mun J. Real Options Analysis Course. Business Cases and Software Applications. New Jersey: John Wiley \& Sons, Inc, 2003. 318p.

12. Solodka O.O. Parameters of pricing of forward and futures contracts. International Research Conference on Science, Education, Technology and Management: Conference Proceedings, August 20th 2017. Scientific public organization Professional science. Paris: Scientific public organization Professional science, 2017. 455p. P.269-286.

13. Solodka O.O. The methodology of fundamental and technical analysis in the context of the market's irrationality of derivatives. International Research Conference on Economics, Arts and Sciences: Conference Proceedings, 31 July 2017. Scientific public organization Professional science. Uppsala: Scientific public organization Professional science, 2017. 416p. P.276-301. 